\title{
Do CITES trade restrictions work? Some evidence from the markets for sawfish trophies
}

\author{
Santiago Gómez-Rodríguez ${ }^{*}$ and James R. Wilson \\ Université du Québec à Rimouski, 300, allée des Ursulines, C.P. 3300, succ. A, Rimouski (Québec) G5L 3A1, Canada
}

Received 6 October 2020 / Accepted 20 January 2022

Handling editor: Olivier Thebaud

\begin{abstract}
The durability of animal parts that are collected and traded as trophies has an impact on species sustainability, especially when animals are slow-growing, have low fecundity, or are particularly vulnerable to capture. CITES (the Convention on International Trade in Endangered Species of Wild Fauna and Flora), aims to control the trade of wild fauna and flora specifically by using trade restrictions as a policy option. However, specialists in international trade have advised against using trade restrictions to correct social cost issues. The reasons for this advice have to do with the unintended economic consequences of animals being placed on an endangered species list, coupled with the trade restrictions themselves. We focused on Pristis spp. (sawfish), a species in danger of extinction found in Appendix I of the CITES convention. An extensive search of sawfish saws for sale on the internet was performed during 2016 and 2017. A total of 174 observations of market prices were collected. We estimated several models linking prices to the size of the saw with other variables that might explain price variability using OLS regression, and which included data from both the original internet searches and additional variables, including a dummy variable which indicated the year in which the species group was placed in Appendix I. These models show that rather than slow down the extinction pathway for this species, CITES may have sped it up, as well as driving the sawfish trophy markets underground.
\end{abstract}

Keywords: Sawfish / extinction / international trade / CITES / policies

\section{Introduction}

Many species of terrestrial flora and fauna might be classed as common pool resources, and the interactions between fish stocks and fisheries are often classic examples of the common pool problem. Governments are often forced to take on the management of these goods, in the interests of economic viability of the resource users and for the sustainability of the resource. In cases where they do not, common pool equilibriums in which a species is biologically and economically over-exploited become the norm (Gordon, 1954).

Public management measures in fisheries are often far from sustainable and efficient. History suggests that there have been many cases of chronic underinvestment in public management of fisheries. As a result, fisheries are frequently overexploited. In some cases, fisheries have been exploited at such a pace that the scarcity rent dissipates completely, and total costs of fishing eventually equals the total revenue derived from it. Stocks of fish that are slow growing, have low fecundity or low

\footnotetext{
*Corresponding author: santiago.gomezrodriguez@uqar.ca
}

intrinsic rates of growth, and are particularly vulnerable to capture, are especially subject to extinction (Bjørndal and Conrad, 1987; Gordon, 1954; Schaefer, 1957).

Trade restrictions might have appeared to be an obvious policy response to reduce the risk of extinction of some species. The Convention on International Trade in Endangered Species of Wild Fauna and Flora (CITES) agreement is an example of such a policy. CITES is the largest multilateral agreement on wildlife trade of commercial interest, and it regulates trade in more than 30,000 species of animals and plants, through a system of certificates that allows trade in species under certain circumstances. The CITES convention has three Appendices, ranging from one that enumerates species threatened with extinction (Appendix I), to ones that enumerate species needing joint protection from members (Appendix II and III). Each appendix has different levels of trade controls aimed at controlling overexploitation (CITES, 2019).

CITES is a voluntary agreement dating from 1975 aimed at preventing trade of endangered species. CITES tries to achieve this goal using the commitments made by each of the members within a group of members called a Party (CITES, 2019). In a search for agreement among Parties, CITES uses a combination 
of "carrots" and "sticks" (Reeve, 2002). One example of a "carrot" is that members are provided with training, species identification manuals, and technical assistance (CITES, 2019). The "sticks" are the sanctions that members accept in the case of non-performance.

Sawfishes (family: Pristidae), belong to the group of elasmobranchs in the order Pristiformes that is composed of two genera and five species; Pristis pristis, P. clavata, P. zijsron, P. pectinata, and Anoxypristis cuspidata (Faria et al., 2013). The Pristdae family is characterized by an elongated saw with large teeth on each side (Cervigon and Alcalá, 1999; Fischer et al., 1987). The life history of these populations makes them easy targets for over-exploitation. Sawfishes are viviparous (or live-bearing) and have low fecundity, slow growth, late sexual maturation and a low intrinsic rate of growth (Simpfendorfer, 2000), as is the case with many sharks and rays. Growth and reproductive effort in fishes are closely correlated with body size. Live-bearing can reduce a female's mobility, which increases her risk of predation and capture by fishnets (Fitch, 1970; Goodwin et al., 2002; Thibault and Schultz, 1978).

The Pristiforms were placed in Appendix I of the CITES endangered species list in 2007. Since 2007, CITES convention forbid the trade of any body part of these protected species. However, in the case of the sawfish, the saw and in some cases the fins are still being traded (CITES, 2016; IUCNRedList, 2019). Parts of sharks in particular are considered "luxury goods" in many countries (Caddy and Mahon, 1995), in the sense that rising real incomes for these goods provokes an increased demand, thereby exacerbating the possibilities of extinction.

Sawfishes are considered one of the most endangered groups of marine animals in the world (Dulvy et al., 2014), due to high mortality from incidental fisheries, habitat destruction or modification and pollution, bycatch, collisions with boats, wounds from propellers, and targeted capture for the sale of saws and fins. The risk of mortality by each of these factors increases with sawfish size (Seitz and Poulakis, 2006). Recovery of a population can take decades or longer depending on how effectively sawfish are protected (Simpfendorfer, 2000). Sawfishes have been declared locally extinct in the Caribbean sea of Colombia and Venezuela (Gomez-Rodriguez et al., 2014) and are currently at risk of extinction in North America (Dulvy et al., 2014).

We analyzed the market prices of sawfish saws, because price is an important indicator of resource scarcity. One of the things that economics examines is the role of formal and informal rules, and how they change human behavior. A re-distribution of resources in an economy resulting from these behavioral changes often results. Some of these changes have intended consequences, but others have consequences that are unintended. Some of these may even have unintended and negative consequences. The intuitions of those proposing trade restrictions for various reasons provides examples of unintended negative consequences. Prices of goods, and the price system in general, are an integral part of any analysis whenever a market is present, because prices are related not only to the rules of that market, but also to the determinants of both the demand (or marginal value), and the supply (or marginal cost) of the good. Price is therefore an important signal that measures the consequences of a rule change. Studying this as well as other impacts will help determine if a rule is ultimately desirable. For example, placing trade restrictions usually reduces trade volume, but it also raises prices for the restricted good (e.g. ivory) (Kremer and Morcon, 2000). These price changes may however incite over-exploitation of the underlying asset (in this case, the animal itself) especially in poorer countries where public management of goods may be less developed. For this reason, it is hard to imagine any attempt at managing public goods like fisheries resources, without at the same time investigating markets, market structures, as well as prices and the price system.

For these reasons, understanding the production and marketing chain of the body parts is important in determining the risks of environmental and economic loss associated with the overexploitation of this species group. Given that respected specialists in international trade (see Krugman et al., 2015) have raised questions about the economic efficiency of trade restrictions generally, what are the effects, if any, of trade restrictions aimed at protecting animal species, and what are the consequences of these policies? Since price is an important indicator of scarcity and can also change human behavior, what might be the broader effects of such policies? The trade restriction makes it more costly for producers to provide the good in question, thus increasing marginal cost, thus raising prices. In either case, if the public resource is not managed efficiently, rising prices of endangered species provoke poaching and eventual extinction. We agree that this needs more research, but even more importantly, we believe that more attention should be paid to actual markets for endangered species, including the collection of price data. This is not presently being done by CITES.

\section{Data gathering}

During 2016 and 2017, an extensive search of the selling prices of sawfish saws on the internet was performed. The parameters of the search, on Google, included "sawfish saws or sawfish parts, sawfish bills, marine animal parts, Pristis saws, Pristis bills, shark sword + sale" in five different languages: English, Spanish, French, Chinese, and German. The search led us to several different live and online auction houses (Christie's, Sotheby's, eBay, Auction Co., Classifieds, Kijiji, iBazar, GittiGidiyor, Gumtree, G-Market, StubHub, Half.com, Marktplaats.nl, among others). Historic searches of publicity on Google was used to find other saws. Other suggestions by Google were also important to finding some saws. Another important method to find some prices and saws was through communication with other researchers, who kindly shared databases which contained information that complemented our database. Most of the saws found belonged to private collections and were offered in different auction houses and on sale pages. A total of 174 observations were collected, but because of missing data for some entries, such as length, price, origin, year etc., 115 were used for analysis.

These Data were classified by Item (if it's a saw or a tooth); Species; Price (in local nominal currency); real US prices at the time of sale; Size (in millimeters); Country where the item was offered for sale, and the Year the item was sold (2002-2016). A binary variable was included to indicate whether the seller was an auction house. Price formation in auction houses will 
yield prices which tend to be higher than in a disaggregated market, because the auction house uses bidding protocols aimed at revealing maximum willingness to pay among a group of buyers. The models we ultimately estimated were based on a time series with multiple cross-sectional observations within some years ${ }^{1}$.

\section{Analysis of data}

Using data at hand, we wanted to better understand the main drivers of sawfish saw prices. The saw size was one important variable determining real price. We used saw prices as a dependent variable because, like certain elephant parts, the saw is a storable good, like many other animal part trophies (Kremer and Morcom, 2000). Bockstael and McConnell (2007) have argued that when the prices of a market good are regressed against the measurable but non-market characteristics of that good, the tangencies (or equilibriums) between a number of bid functions for individual sellers and buyers is what is being estimated. This is the theoretical foundation of the hedonic pricing method. For this study, a hedonic price function was estimated with data at hand. This method relies on the hypothesis that the price of a commodity exchanged on a market is influenced by its measurable characteristics that are not necessarily traded directly on the market. The assumption is that economic agents hold values for the product based on its attributes, and so implicit or hedonic prices exist depending upon those attributes (Bockstael and McConnell, 2007; Malvarosa et al., 2006). The resulting estimation is the hedonic price equation. Assuming that the parameters of the nonlinear function are less than 1 , the first derivative of the hedonic price equation is, in some sense, the marginal value, or demand, for the "average" consumer for a given attribute. In this more restrictive case, the marginal value also conforms to the neoclassical assumptions of consumer choice. But since hedonic price functions are the reduced forms of a system of simultaneous equations between the bid functions of buyers and sellers, we only have the equilibrium points of those bid functions to work with, in part because of the limited economic data reported by CITES.

A regression was estimated using data from both the original internet searches and the additional variables, which include binary variables. These take on a value of 1 for some data points and zero otherwise. For the regressions, different specifications were tried to explain variability of prices. We were concerned with untangling the effects of CITES, represented in one of our binary variables, with the other effects related to time. To do this, we added a trend and, for some specifications, a variable TREND*CITES07. This was intended to address the question: what effect might CITES have had on the trend in prices as represented by the slope of the trend variable?

We used the binary variable CITES 07 (2007 was the year that all species of Pristidae entered Appendix I). Pre-CITES observations had a value of 0 , and from 2007 on, they had a value of 1 . Country, Size and a binary variable to identify sales made through auction houses (Auction Houses) were also included in some models. We used a deflator provided by the

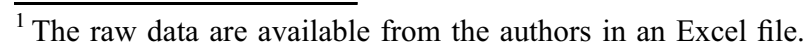

World Bank (2017), to find the real price at purchasing power parity. Finally, we used the Chow test (Chow, 1960) to verify that the variable CITES DUM 07 is an important explanatory variable for the price of saws. The calculated $F$ value was 5.20, which is significant at more than the $95 \%$ level (with $k=4$ and $N=107)$.

\section{Results and analysis}

Three models were used to show the possible scenarios influencing the sawfish saw market, a market that was to be restricted by CITES from 2007. The first model we presented was significant, and was the most robust model (Tab. 1). A loglog specification was estimated with the independent variables SIZE (log of the length of the saw in millimeters); CITES DUM 07 (a dummy variable that relates date of sale to the date that the CITES treaty came into force); and DUMCITES07*LNTREND. To do this, a TREND variable was created starting at 1 in 2002, increasing to a value of 15 in 2017. LNTREND is the natural logarithm of TREND. Then DUMCITES07*LNTREND was formed. The combination of these two variables tried to measure the change in the slope of the trend before and after the addition of sawfish to Appendix I of CITES. This regression showed that the parameter associated with this instrumental variable was negative, suggesting that the effects of the trend on prices were less after the species was added to Appendix I of CITES.

The second model tried to untangle the effects of time and the effect of CITES on saw prices. The model was significant, but we know that other unidentified variables could explain more variation (Tab. 1). However, a more complete specification is likely not possible because these data are not systematically collected by official statistics of CITES. The same $\log -\log$ specifications were estimated using LNSIZE, trend, and the CITES dummy variable.

The third model performed less well than the other two models (Tab. 1). We hypothesized that saws sold in an auction house would have higher prices than saws of the same size sold in another manner, because auction methods tend to maximize the extraction of consumer surplus by using different protocols that encourage bidding. For this reason, we included the binary variable AUCTION HOUSES to our model. The variable AUCTION HOUSES was not significant in this model. These results, in addition to the results presented by the second model, suggest that saw prices had been steadily falling over time, but these price declines slowed after CITES. It is possible that CITES has created the price increases over time, or that the agreement has possibly counteracted trends that were already occurring.

A test for multicollinearity was performed to determine if correlations between explanatory variables had an effect on model performance (Criddle, 2007). The analysis shows that there was no multicollinearity in any of the models presented. The Haitovsky chi-square singularity test confirmed that there was no singularity between the variables. Akaike Information Criterion (AIC) was performed using Statgraphics 19 (Tab. 1).

We found a positive and significant correlation between size of saw and real prices paid. However, we also found that the addition of Pristis spp. on Appendix I of the CITES agreement may have led to higher prices for the saws. This is 
Table 1. Estimated values for three tested models.

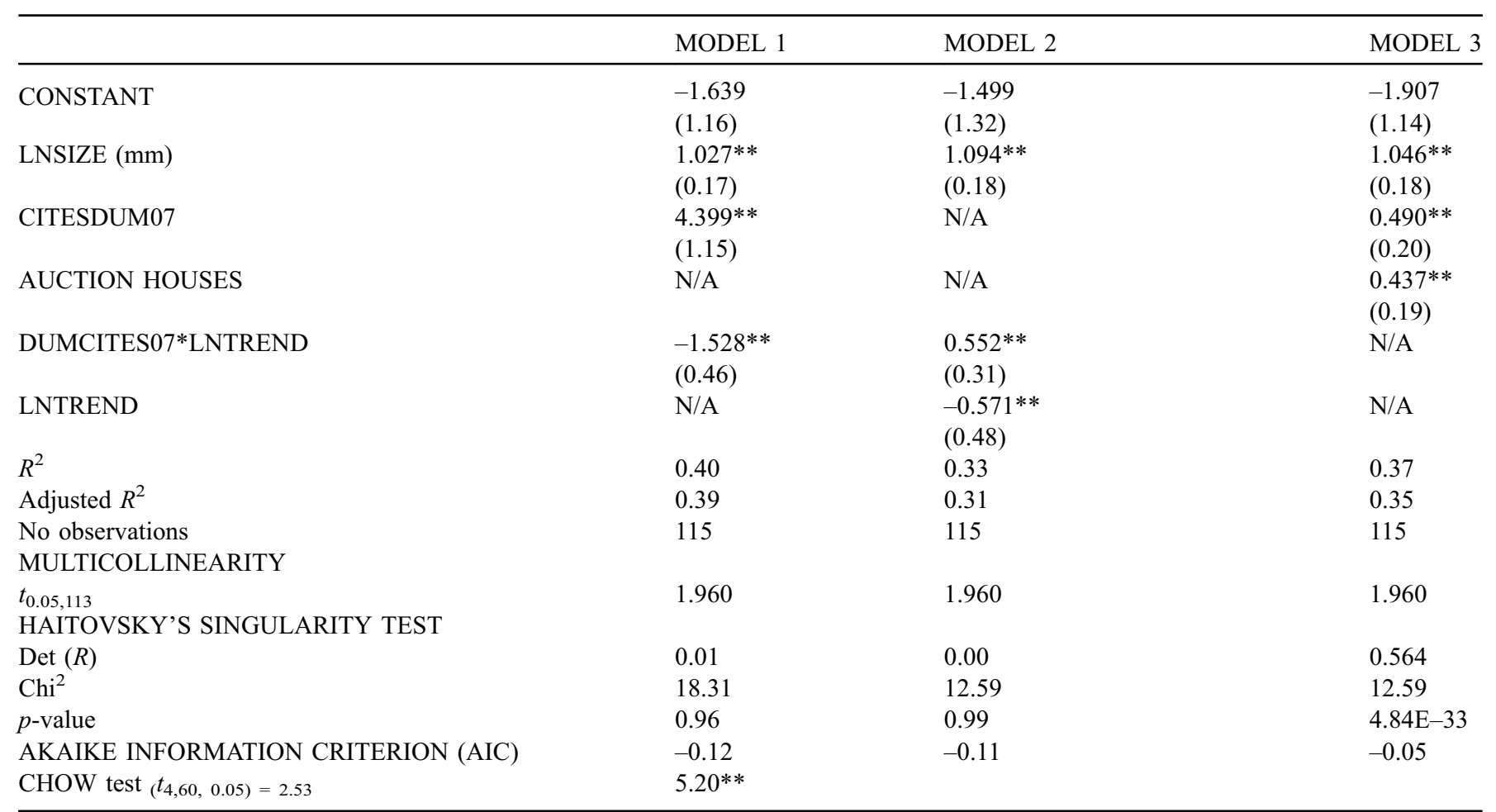

\footnotetext{
${ }^{* *}$ Indicates significance at the $95 \%$ level.
}

an interesting result because it suggests that placing the species in Appendix I of the CITES agreement did had an effect; however, that effect may have had a negative impact in terms of sustainability of the species, because increasing prices for these parts may provide additional incentives to retain captured fish.

There was also a relation between higher prices and whether the product was sold in an auction house. If the sale was recorded from an auction house, the price was higher than the items that were sold on web pages.

We take as an example the antilog of our first model to explore some of the implications of this estimation. The antilog of the model 1 in Table 1 is:

price $=e^{-1.639} \operatorname{size}^{1,027} e^{4.399 * \text { CITESDUM07 }} e^{-1.528 * \text { CITESDUM07*LNTREND }}$

For continuous variables (size), the parameter estimates are elasticities, or the percentage change in price for a percentage change in the value of the regressors, while for a binary variable the parameter is a multiplier that either increases or decreases the entire function. The introduction of Pristis spp. on Annex I of CITES, increased trophy prices by a factor of $\mathrm{e}^{4.399}$. This result was corroborated with a Chow test (Tab. 1).

\section{Discussion}

Our analysis raises questions about how nations go about discouraging species extinction and promoting conservation. Over-exploitation and extinction are above all social cost problems, usually created by common pool resource use. Problems like these may require finer-edged policies than trade restrictions, which in many ways are "blunt stick" approaches to dealing with social costs related to trade. Trade restriction policies often do not consider the unintended consequences of the policy and changing incentives among traders. A country could deal with these social costs more directly in other ways, such as imposing taxes on resource throughput, by improving education, or by the development of specific local management rules for promoting conservation. Although trade in the parts of endangered species such as Pristis spp. carries a social cost, this species group is often having sustainability problems because member countries do not have clear public management plans in place for these species in their own territories. Our analysis suggests that trade bans in this context may exacerbate extinction pathways. Management plans also need to take account of the social and economic conditions of the fishers who are doing most of the damage. For these reasons, CITES advocates should consider re-directing their policies to cover some of the issues related to these social costs, as Krugman et al. (2015) has argued in the broader context of protectionism and trade. Both developed and developing countries have their own special arguments for imposing all manner of trade restrictions, but few of these arguments are very convincing, which is why trade policies to correct social cost issues are considered by many economists to be secondbest solutions, sometimes causing more problems than they solve.

There are other policy opportunities besides trade restrictions that become evident by considering economic behavior. The likelihood of a sawfish being kept after 
accidental capture increases with the size of the individual. Since larger individuals of this species class bear more live young than smaller individuals, it is reasonable to assume that the price signals for larger animals are one of the factors that will accelerate species extinction, and will become more likely as more, and different, parts are traded. To protect the species, it may become necessary to develop policies aimed at both conservation and education. It is also necessary to have enforceable "no take" laws at a more local level.

Other areas of improvement would be to understand the technologies that cause the problem of accidental sawfish catches in the first place. According to FAO (2016), the probability of a sea turtle getting entangled in a gillnet, the gear most used by artisanal fisheries, increases at night. Gillnets also entangle sawfish. For that reason, local governments could encourage reduced soak times for gear, or increase the number of checks on the gear, to increase survival and minimize discards of entangled bycatch, this reduces the risk of capturing non-target species and prevents the discarding of dead or unsalvageable animals. As an example (NMFS and NOAA, 2010), recommend: "to limit soak times to 24 hours when using sink gillnet gear and vessels using drift gillnet gear will need to conduct net checks at least once every 2 hours to look for and remove any sea turtles, marine mammals, or small tooth sawfish".

The dependent variable in our models is the real price of a saw at purchasing power parity. This means that both inflation and differences in cost of living are accounted for. Inflationary trends therefore should not be conflated with the pre-CITES/ post CITES analysis we present. There may be additional factors that influence prices due to, for example, rising real incomes in Asia. However, the variable CITESDUM07 in these regressions does suggest at least a coincidence between CITES placing Pristis spp. on Appendix I and price rises in the market for saws that should be explored in more detail. If a CITES Appendix I designation indeed ended up accelerating extinction pathways by driving up prices of sawfish saws and driving markets underground, this would weaken the case for CITES style policy responses.

The results we found in this case resemble other cases, such as the big leaf mahogany in Brazil, a tree prized for its high quality and durable timber. According to Chimeli and Boyd (2010), CITES added Brazilian mahogany to Appendix II in 2002 over the objections of the Brazilian government. However, this prohibition of trade in mahogany increased the supply response of sellers on the informal market. This result is different from the predictions of other literature on trade in prohibited goods. If there is no possibility of underground markets developing, the marginal costs of production under trade prohibitions would of course increase, leading to a reduction in the equilibrium quantities exchanged and an increase in prices. But the unintended consequence in this case was the enlargement of the informal market.

There are other cases related to terrestrial species that should raise red flags for managers. The listing of all rhino species in Appendix I failed to stop trade and/or poaching. However, trying to solve internal social cost issues in importing and exporting countries did. In the mid-1990s, almost all major traditional consuming countries/territories in Asia, including China, Hong Kong, Japan, South Korea and Taiwan, adopted their own rhino horn trade policies. This, as well as meaningful demand reduction efforts within these countries, helped matters. South Africa and Zimbabwe adopted domestic measures such as dehorning and moving populations to a few intensive protection zones. This strategy led to a temporary decline in poaching and since 1986, the Natal Parks Board has auctioned white rhinos to the private sector, and from 1990, black rhinos as well. Increasing demand and rising prices for live rhinos also ensured that private landowners had a stronger incentive to conserve and sustainably manage rhino populations. This is considered by many as a rare conservation success story ('t Sas-Rolfes, 2000; Milliken and Shaw, 2012). However, it was a success story in part because it dealt with economic incentives of those directly involved. In the case of marine species such as Pristis spp., the possibilities for putting successful incentive-based measures in place may be more challenging. Rhino management on dry land with physical barriers like fences might be less costly than Pristis spp. management in an aquatic environment, often with various parts of it managed by several layers of government.

The implication of this analysis is that the inclusion of Pristis spp. in Appendix I of CITES may have been disadvantageous for these species. The prices of sawfish saws appears to have increased after 2007 , and may have led to the emergence of a black market for sawfish parts, especially the saws (Pires and Moreto, 2016). Black markets may have been more problematic for conservation efforts, because in driving the market underground, it becomes harder to control and monitor accidental capture, and to accurately perform market analysis. Fisherman who catch sawfish may have incentives to sell the animal in parts to be able to pay for the repair of fishing gear, such as gillnets (personal communication fishers of Don Jaca, Santa Marta, Colombia, 2014). Additional tax-free income by selling the parts can be tempting as well.

Policies aimed at improving catch-and-release survival rates might also be explored, including publicity and education on how to release these fish unharmed. An important first step could be the development of workshops for fishers that teach them what to do in case they catch different endangered species including sawfish, and what techniques scientists recommend for avoiding permanent injury to animals. The facilitation of this education is important, not just in locations where fishermen gather but also in the media, where explaining the life history of sawfish and the reasons for protecting them are also important steps. Spreading such publicity in stores that sell fishing equipment and on docks used by commercial and recreational fishers is currently being used to ensure compliance with regulations in some countries. Other policies are aimed at protecting habitat, such as restricting construction near or in mangroves, because these are the habitats of sawfish and other important marine species, such policies would also be important to explore and put in place, as NMFS and NOAA (2010) have done in some of their management plans.

Following the recommendations of the IUCN Shark Specialist Group (SSC) may also be useful. These were designed not only from a fisheries and ecological point of view, but they also have a social and trade component that includes the improvement of field data through observers, as well as joint work with non-governmental organizations like TRAFFIC organization and CITES to improve the implementation of Appendix I. Also the use of cell phone technologies and other application through the internet could be used for the better management of sawfish (Harrison and Dulvy, 2014). 
The decline of fisheries worldwide may force a change in the way resources are managed and in the way resource managers deal with human behavior. The obvious fixes, such as increased trade regulations that are difficult to enforce, may make things worse. It may be necessary to break with the old paradigms and generate new approaches that can overcome the gaps in the management of captured species. These should particularly focus on policies that deal directly with the economic incentives faced by humans, which may mean focusing on research projects that explore the interactions between human behavior and exploited animal populations. Policies that are focused on human behavior, as well as the life history of the animal in question, stand a greater chance of achieving sustainability. For example, campaigns to reduce demand for shark fins and other products from endangered species, especially in countries where the real incomes of citizens are rising rapidly seem to have some traction. Factbased information that can change human perceptions could cause dramatic changes in demand.

If each nation had unlimited resources and/or competent agencies, the care of wildlife would not have to be regulated by any convention (Martin, 2000). However, in the case at hand, where CITES seems to influence trade, it may be useful to consider revising the rules of the game. Having three appendices instead of one may generate gaps in local legislation and management, thus allowing smugglers to take advantage and continue to traffic species included in the appendices (du Plessis, 2000). To remedy these gaps, Martin (2000) made three recommendations to improve CITES: (1) have a single appendix where all the species of international importance are, and focus on programs for each species; (2) Take into account the needs of each country in managing the trade in species and decentralize the strategy, and (3) CITES and the Convention on Biological Diversity (CBD), should join forces, since although they are interested in the conservation of wildlife, the first one attempts to use economic policies while the second focuses on ecosystem protection.

Unfortunately, neither CITES nor other wildlife protection agencies we consulted, have reliable databases on the volumes of capture or trade (legal or illegal) on this species. In a conversation with a CITES agent, he was quoted as saying: "CITES does not regulate or have records on domestic trade, nor do we generally have information about market prices, be it legal or black market" (Kachelriess, 2016 personal communication). However, CITES should focus on all markets, including black markets, as well as the drivers of prices in these markets, to become more effective at predicting sustainability problems before they occur. There is also very little information available about the trade of sawfish products in general (NMFS and NOAA, 2010). Since 2006, the big websites such as eBay and Amazon have banned the sale of animal parts. However the ban was not established for all sawfish species (NMFS and NOAA, 2010). Most of the saws found included the CITES certification that allows for trading before the sawfish was added to the Appendices; or the owners claimed that the saw came from the 19th century, and thus was obtained outside of the time periods of the CITES ban.

In order to more accurately measure the performance of policies like those of CITES, researchers need to have access to more and better market data, which usually are incomplete or poorly collected (Abensperg-Traun, 2009; Watson and Pauly, 2001). If that were to happen, more detailed supply and demand analyses could be performed. But since these data seem not to be widely available, hedonic price analysis using unconventional data sources from the internet was used as an alternative approach.

Acknowledgements. We thank Dr. Matthew McDavitt for sharing his data with us, as well as the Ressources Aquatique Québec (RAQ) who funded the presentation of this material.

\section{References}

Abensperg-Traun M. 2009. CITES, sustainable use of wild species and incentive-driven conservation in developing countries, with an emphasis on southern Africa. Biol Conserv 142: 948-963.

Bjørndal T, Conrad JM. 1987. Capital dynamics in the North Sea Herring fishery. Mar Resour Econ 4: 63-74.

Bockstael NE, McConnell KE. 2007. Hedonic Models of Heterogeneous Goods. In: Environmental and Resource Valuation with Revealed Preferences. Netherlands: Springer, pp. 151-187.

Caddy JF, Mahon R. 1995. Reference points for fisheries management. FAO Fish. Tech. Pap. No. 347. Rome: FAO, 83p.

Cervigon F, Alcalá A. 1999. Los peces marinos de Venezuela. Vol V. Caracas: Fundación Museo del Mar, pp 230.

Chimeli AB, Boyd RG. 2010. Prohibition and the Supply of Brazilian Mahogany. Land Econ 86: 191-208.

Chow GC. 1960. Tests of equality between sets of coefficients in two linear regressions. Econometrica 28: 591-605.

CITES. 2016. Convención sobre el Comercio Internacional de Especies Amenazadas de Fauna y Flora Silvestres. (www.cites. org/sites/default/files/eng/app/2016/S-Appendices-2016-03-10. pdf).

CITES. 2019. What is CITES? www.cites.org/eng/disc/what.php.

Criddle KR. 2007. Intermediate statistics and applied regression analysis. Third Edit, East-West Bridge Publishing House.

du PlessisMA. 2000. CITESand the causes of extinction. In:Hutton J., DickinsonB. (Eds.), Endangered Species Threatened Convention: The Past, Present andFuture of CITES. London: Earthscan Publications Ltd.

Dulvy NK, Davidson LNK, Kyne PM, Simpfendorfer CA, Harrison LR, Carlson JK, Fordham SV. 2014. Ghosts of the coast: Global extinction risk and conservation of sawfishes. Aquat Conserv Mar Freshw Ecosyst 26: 134-153.

FAO. 2016. The State of World Fisheries and Aquaculture 2016. Contributing to food security and nutrition for all. Rome: FAO, $200 \mathrm{pp}$.

Faria VV, McDavitt MT, Charvet P, Wiley TR, Simpfendorfer CA, Naylor GJP. 2013. Species delineation and global population structure of Critically Endangered sawfishes (Pristidae). Zool J Linn Soc 167: 136-164.

Fischer W, Bauchot ML, Schneider M. 1987. Fiches FAO d'identification des espèces pour les besoins de la pêche. (Révision 1). Méditerranée et mer Noire. Zone de pêche 37. Volume II. Vertébrés. Publication préparée par la FAO, résultat d'un accord entre la FAO et la et la Commission des Communauté.

Fitch HS. 1970. Reproductive cycles in lizards and snakes., Univ. Kansas Mus. Nat. Hist. Misc. Fb\&c Limited, pp 247.

Gomez-Rodriguez S. Caldas JP, Acero PA, Martinez-Silva MA, Saenz-Okuyama P, Lasso CA, Lasso-Alcala OM. 2014. Geographic distribution and conservation status of sawfish Pristis spp (Pristiformes: Pristidae) in the southern Caribbean Sea. Biota Colomb 15: 3-25. 
Goodwin NB, Dulvy NK, Reynolds JD. 2002. Life-history correlates of the evolution of live bearing in fishes. Phil Trans $R$ Soc Lond B 357: 259-267.

Gordon HS. 1954. The economic theory of a common-property resource: the fishery. J Polit Econ 62: 124-142.

Harrison LR, Dulvy NK. 2014. Sawfish: A Global Strategy for Conservation, IUCN Species Survival Commission's Shark Specialist Group, Vancouver.

IUCNRedList. 2019. Sawfish [WWW Document]. URL https://www. iucnredlist.org/species/18584848/141788242

Kachelriess D. 2016. Marine Species Officer (JPO) CITES Secretariat, Scientific Services Team. Personal communication.

Kremer M, Morcom C. 2000. Elephants. Am Econ Rev 90: 212-234.

Krugman P, Obstfeld M, Melitz M. 2015. International economics: Theory and Policy. 10 Edition. France: Pearson, pp 754.

Malvarosa L, Daures F, Leblond E, Andersen JL, Andersen KN, Nielsen R, Anton S, Curtis H, Buisman E, Salz P. 2006. Evaluation of the capital value, investments and capital costs in the fisheries sector, Final report of the project FISH/2005/03. https://data collection.jrc.ec.europa.eu/documents/10213/481e4f1c3cb3-4c60-84ed-3b879211b3b6.

Martin RB. 2000. When CITES works and when it does not. In: Hutton J., Dickson B. (Eds.), Endangered Species Threatened Convention: The Past, Present and Future of CITES. London: Earthscan Publications Ltd, pp 29-37.

Milliken T, Shaw J. 2012. The South Africa Viet Nam rhino horn trade nexus: a deadly combination of institutional lapses, corrupt wildlife industry professionals and Asian crime syndicates. Traffic.

NMFS, NOAA. 2010. Status Review of the Largetooth Sawfish (Pristis perotteti). National Marine Fisheries Service National
Oceanic and Atmospheric Administration. https://repository. library.noaa.gov/view/noaa/16287.

Pires SF, Moreto WD. 2016. The Illegal Wildlife Trade. Oxford Handbooks Online. https://www.researchgate.net/publication/ 304998952_The_Illegal_Wildlife_Trade. Oxford Handbooks Online.

Reeve R. 2002. Policing international trade in endangered species, the CITES treaty and compliance. London: The Royal Institute of International Affairs and Earthscan Publications Ltd., pp 346.

Schaefer MB. 1957. Some considerations of population dynanics and economics in relation to the managernent of the comercial marine fisheries. J Frsu Rrs Bo 15: 669-681.

Seitz JC, Poulakis G. 2006. Anthropogenic effects on the smalltooth sawfish (Pristis pectinata) in the United States. Mar Pollut Bull 52: 1533-1540.

Simpfendorfer CA. 2000. Predicting population recovery rates for endangered western Atlantic sawfishes using demographic analysis. Environ Biol Fishes 58: 371-377.

The World Bank. 2017. Inflation, GDP deflator (annual \%) [WWW Document]. URL https://data.worldbank.org/indicator/NY.GDP. DEFL.KD.ZG

Thibault RE, Schultz RJ. 1978. Reproductive adaptations among viviparous fishes (Cyprinodontiformes: Poeciliidae). Evolution (N. Y). 32: 320-333.

't Sas-Rolfes M. 2000. Assessing CITES: Four cases studies. In: Jon Hutton and Barnabas Dickinson (Ed.), Engangered Species Threatened Convention: The Past, Present and Future of CITES. 1st Ed, London, Earthscan Publications Ltd, p. 202.

Watson R, Pauly D. 2001. Systematic distortions in world fisheries catch trends. Nature 414: 534-536.

Cite this article as: Gómez-Rodríguez S, Wilson JR. 2022. Do CITES trade restrictions work? Some evidence from the markets for sawfish trophies. Aquat. Living Resour. 35: 2 